\title{
Healthcare Systems Need to be Organized to Fight two Pandemics Simultaneously
}

\section{Partha Basu}

Head, Screening Group, Early Detection and Prevention Section, International Agency for Research on Cancer, Lyon, France.

$$
\text { Asian Pac J Cancer Care, } 5 \text { (Suppl 1), 1-3 }
$$

Corona Virus Disease (COVID-19) dashboard shows that the pandemic caused by SARS-CoV-2 of the World Health Organization (WHO) virus has claimed about 450,000 lives across the globe within six months since the first reported outbreak in December 2019 [1]. The COVID-19 outbreak has strained the health systems to the extreme and will deeply impact their capacity to tackle the other ongoing pandemic, caused by the growing burden of cancer.

A pandemic is defined as "an epidemic occurring worldwide, crossing international boundaries and usually affecting a large number of people" [2]. Going by that definition, the world has been grappling with cancer pandemic much before COVID-19 struck. Cancer, causing nearly 10 million deaths every year, ranks as the number one cause of premature mortality in 48 countries, second in 43 countries and third or fourth in another 22 countries of the world [3]. In rest of the 58 countries the disease ranks among five to ten leading causes of premature deaths.

SARS-CoV-2 infection creates a huge burden on the health infrastructure as it spreads very fast and has high infection-fatality ratio (IFR), 5-10 times that of seasonal influenzas [4]. European data shows that nearly one fifth of the COVID-19 patients require hospitalization, $9 \%$ of those hospitalized require intensive care management and the case fatality is extremely high above the age of 60 years [5]. The health infrastructure is further crippled by the fact that $20 \%$ of all people infected are frontline health providers. A weakened health system with priorities shifting back to infectious disease control will have a long term impact on the management of the patients with suspected or diagnosed cancer and also on the cancer prevention interventions delivered through public health programmes.

Two recently published studies in the Lancet clearly show that treating cancer patients during the epidemic does not increase COVD-19 related mortality. The authors strongly argue that withholding treatment would cause significantly more harm than COVID-19 itself, for the
Submission Date: 06/22/2020 Acceptance Date: 06/29/2020

cancer patients. The COVID-19 and Cancer Consortium published data on 928 adults with active or past cancer (median age 66 years, 39\% on active anticancer treatment) who had confirmed coronavirus infection [6]. All-cause mortality among these patients recruited in Spain, Canada and the USA was $13 \%$ within 30 days of diagnosis of infection. The risk of mortality increased with increased age, male sex, former smokers, associated comorbidities, active cancer and poor performance score. The reassuring finding was that recent anticancer treatment including surgery did not increase mortality. The UK Coronavirus Cancer Monitoring Project reported that $28 \%$ of 800 cancer patients with Coronavirus infection died; $93 \%$ of the deaths were due to COVID-19 [7]. Risk of death was significantly associated with the factors identified by the study mentioned earlier, but not with administration of immunotherapy, chemotherapy, radiation therapy or targeted therapy within 4 weeks of detection of SARS-CoV-2.

Cancer itself is a major co-morbidity that increases risk of death due to COVID-19, but harm-benefit ratio clearly tilts in favour of offering stage-appropriate treatment for the cancer patients without any delay. The oncology centers will continue to face major challenges due to the restrictions imposed on out-patient consultations and in-patient admissions to implement social distancing. There will be shortage of staff as some of them get infected and/or exposed and are forced to be in quarantine and disruption of supply chains for essential chemotherapeutic drugs. Organizations like European Society of Medical Oncology have published guidelines on how to continue patient care in spite of the pandemic [8]. Educating the patients as well as the staff on personal protection, maintaining social distancing as much as possible even during clinical interactions, adequate amount of protective equipment for staff as well as patients, and regular testing of patients undergoing treatment to identify, triage and treat the COVID-19 patients early are some of the key recommendations. Each oncology center should develop 
its standard operating practice in consultation with such international and national guidelines. Teleconsultation to monitor patients on oral medications or for follow up should be promoted.

The COVID-19 pandemic should not be allowed to overshadow the cancer control activities. It is difficult to predict the duration of the pandemic. Hence, some of the cancer control measures that have been temporarily put on hold as 'non-essential' should be restarted in a pragmatic manner. Many countries have halted hepatitis $\mathrm{B}$ and Human Papillomavirus vaccination programmes due to multiple reasons - overstretched health systems, disruptions in vaccine supply, parent's disinclination to bring children to the health facilities, closure of schools etc [9]. WHO has strongly recommended to resume vaccination activities. The interval between two doses of the HPV vaccine may be extended to at least 12 months to gain some time for the health system to recover. The impact of teleworking and working from home on obesity and reduced physical activity needs to be counteracted with active promotion of healthy practices like avoiding junk food, limited consumption of alcohol and pursuing 150 minutes of exercise of moderate intensity or 75 minutes of exercise of vigorous intensity per week. A systematic review of literature shows that the smokers have 1.4 times higher risk to have severe symptoms of COVID-19, are 2.4 times more likely to require intensive care including mechanical ventilation and 2.4 time more likely to die compared to non-smokers [10]. Educational messages should highlight this as a compelling reason to quit smoking or not to initiate the habit.

Most countries have temporarily withheld cancer screening activities. To adapt to the 'new normal' situation the programmes need to consider changes in screening and diagnostic algorithms to minimize number of visits and client-provider contacts. Switching to HPV self-sampling based screening for cervical cancer, combining diagnosis and treatment in a single visit for the screen positive women are some of the examples. Further research is needed to identify and evaluate an affordable self-testing kit for colorectal cancer screening. Men and women with co-morbidities (diabetes, hypertension, and respiratory illnesses) should have priority access to services to reduce waiting time. Use of protective equipment and frequent hand washing both by clients and providers and liberal use of sanitizers will protect both the individuals attending screening and providers.

Fear of contacting the SARS-CoV-2 infection may dissuade patients with symptoms to seek early medical consultation and lead to delayed cancer diagnosis. The health facilities should continue to practice proper infection control measures and create safe environment for all patients. The pros and cons of tele-consultation for patients with symptoms should be properly assessed. Primary health care providers with their knowledge of local conditions and their close ties with the community are well positioned to respond to the specific health needs of the population and promote cancer prevention and early detection in their community as social activities gradually resume.
The pandemic will have a huge economic impact that will push many people below poverty line and make them victims of growing inequity in accessing both preventive and therapeutic care. The health system needs to be responsive to the specific needs of the population and look beyond controlling the pandemic. The COVID-19 response strategies for the country should incorporate measures to bring back to normal the temporarily derailed NCD control measures and continue planning for the future. Else, the world will face a twin tragedy of large number of premature deaths occurring both from communicable and non-communicable diseases.

\section{Disclaimer}

Where authors are identified as personnel of the International Agency for Research on Cancer/World Health Organization, the authors alone are responsible for the views expressed in this article and they do not necessarily represent the decisions, policy or views of the International Agency for Research on Cancer/World Health Organization.

\section{References}

1. World Health Organization. WHO Coronavirus Disease (COVID-19) Dashboard. Available from: https://covid19. who.int (access 20/06/2020)..

2. Last J, editor. A dictionary of epidemiology, 4th edition. New York: Oxford University Press. 2001;.

3. Bray F, Ferlay J, Soerjomataram I, Siegel RL, Torre LA, Jemal A. Global cancer statistics 2018: GLOBOCAN estimates of incidence and mortality worldwide for 36 cancers in 185 countries. CA: A Cancer Journal for Clinicians. 201809 12;68(6):394-424. https://doi.org/10.3322/caac.21492

4. Okell LC, Verity R, Watson OJ, Mishra S, Walker P, Whittaker C, Katzourakis A, Donnelly CA, Riley S, Ghani AC, Gandy A, Flaxman S, Ferguson NM, Bhatt S. Have deaths from COVID-19 in Europe plateaued due to herd immunity?. The Lancet. 2020 06;395(10241):e110-e111. https://doi. org/10.1016/s0140-6736(20)31357-x

5. World Health Organization. COVID-19 weekly surveillance report. Data for the week of 18 - 24 May 2020 (Epi week 21). Available from: https://www.euro.who.int/ data/assets/ pdf_file/0003/445089/Week-21-COVID-19-surveillancereport-eng.pdf?ua=1 (access 20/06/2020).

6. Kuderer NM, Choueiri TK, Shah DP, Shyr Y, Rubinstein SM, Rivera DR, Shete S, Hsu C, Desai A, de Lima Lopes G, Grivas P, Painter CA, Peters S, Thompson MA, Bakouny Z, Batist G, Bekaii-Saab T, Bilen MA, Bouganim N, Larroya MB, Castellano D, Del Prete SA, Doroshow DB, Egan PC, Elkrief A, Farmakiotis D, Flora D, Galsky MD, Glover MJ, Griffiths EA, Gulati AP, Gupta S, Hafez N, Halfdanarson TR, Hawley JE, Hsu E, Kasi A, Khaki AR, Lemmon CA, Lewis C, Logan B, Masters T, McKay RR, Mesa RA, Morgans AK, Mulcahy MF, Panagiotou OA, Peddi P, Pennell NA, Reynolds K, Rosen LR, Rosovsky R, Salazar M, Schmidt A, Shah SA, Shaya JA, Steinharter J, Stockerl-Goldstein KE, Subbiah S, Vinh DC, Wehbe FH, Weissmann LB, Wu JT, Wulff-Burchfield E, Xie Z, Yeh A, Yu PP, Zhou AY, Zubiri L, Mishra S, Lyman GH, Rini BI, Warner JL, Abidi M, Acoba JD, Agarwal N, Ahmad S, Ajmera A, Altman J, Angevine AH, Azad N, Bar MH, Bardia A, Barnholtz-Sloan J, Barrow B, Bashir B, Belenkaya R, Berg S, Bernicker EH, Bestvina C, Bishnoi R, Boland G, Bonnen M, Bouchard G, Bowles DW, 
Busser F, Cabal A, Caimi P, Carducci T, Casulo C, Chen JL, Clement JM, Chism D, Cook E, Curran C, Daher A, Dailey M, Dahiya S, Deeken J, Demetri GD, DiLullo S, Duma N, Elias R, Faller B, Fecher LA, Feldman LE, Friese CR, Fu P, Fu J, Futreal A, Gainor J, Garcia J, Gill DM, Gillaspie EA, Giordano A, Glace (G, Grothey A, Gulati S, Gurley M, Halmos B, Herbst R, Hershman D, Hoskins K, Jain RK, Jabbour S, Jha A, Johnson DB, Joshi M, Kelleher K, Kharofa J, Khan H, Knoble J, Koshkin VS, Kulkarni AA, Lammers PE, Leighton JC, Lewis MA, Li X, Li A, Lo KS, LoaizaBonilla A, LoRusso P, Low CA, Lustberg MB, Mahadevan D, Mansoor A, Marcum M, Markham MJ, Handy Marshall C, Mashru SH, Matar S, McNair C, McWeeney S, Mehnert JM, Menendez A, Menon H, Messmer M, Monahan R, Mushtaq S, Nagaraj G, Nagle S, Naidoo J, Nakayama JM, Narayan V, Nelson HH, Nemecek ER, Nguyen R, Nuzzo PV, Oberstein PE, Olszewski AJ, Owenby S, Pasquinelli MM, Philip J, Prabhakaran S, Puc M, Ramirez A, Rathmann J, Revankar SG, Rho YS, Rhodes TD, Rice RL, Riely GJ, Riess J, Rink C, Robilotti EV, Rosenstein L, Routy B, Rovito MA, Saif MW, Sanyal A, Schapira L, Schwartz C, Serrano O, Shah M, Shah C, Shaw G, Shergill A, Shouse G, Soares HP, Solorzano CC, Srivastava PK, Stauffer K, Stover DG, Stratton J, Stratton C, Subbiah V, Tamimi R, Tannir NM, Topaloglu U, Van Allen E, Van Loon S, Vega-Luna K, Venepalli N, Verma AK, Vikas P, Wall S, Weinstein PL, Weiss M, Wise-Draper T, Wood WA, Xu W(, Yackzan S, Zacks R, Zhang T, Zimmer AJ, West J. Clinical impact of COVID-19 on patients with cancer (CCC19): a cohort study. The Lancet. 2020 06;395(10241):1907-1918. https://doi. org/10.1016/s0140-6736(20)31187-9

7. Lee LYW, Cazier JB, Starkey T, Turnbull CD, Kerr R, Middleton G. COVID-19 mortality in patients with cancer on chemotherapy or other anticancer treatments: a prospective cohort study. The Lancet. 2020 06;395(10241):1919-1926. https://doi.org/10.1016/s0140-6736(20)31173-9

8. ESMO. Cancer Patient Management During the COVID-19 Pandemic. Available from: https://www.esmo.org/guidelines/ cancer-patient-management-during-the-covid-19-pandemic (access 20/06/2020)..

9. Nelson R. COVID-19 disrupts vaccine delivery. The Lancet Infectious Diseases. 2020 05;20(5):546. https://doi. org/10.1016/s1473-3099(20)30304-2

10. Vardavas C, Nikitara K. COVID-19 and smoking: A systematic review of the evidence. Tobacco Induced Diseases. 202003 20;18(March). https://doi.org/10.18332/ tid/119324

\section{$(1)(9)$}

This work is licensed under a Creative Commons AttributionNon Commercial 4.0 International License. 